\title{
Magnetite Impregnated Lignocellulosic Biomass for Zn(II) Removal
}

\author{
Christopher Asimbaya ${ }^{1}$, Nelly Maria Rosas-Laverde ${ }^{1}$, Salome Galeas ${ }^{1}$, Alexis Debut ${ }^{2} \mathbb{D}$, Victor H. Guerrero ${ }^{1, * \mathbb{D}}$ \\ and Alina Pruna ${ }^{3,4, *(1)}$ \\ 1 Department of Materials, Escuela Politécnica Nacional, Quito 170524, Ecuador; \\ christopher.gab26@gmail.com (C.A.); nelly.rosas@epn.edu.ec (N.M.R.-L.); salome.galeas@epn.edu.ec (S.G.) \\ 2 Centro de Nanociencia y Nanotecnología, Universidad de las Fuerzas Armadas (ESPE), \\ Sangolqui 171103, Ecuador; apdebut@espe.edu.ec \\ 3 Institute of Materials Technology, Universitat Politècnica de València, 46022 Valencia, Spain \\ 4 Center for Surface Science and Nanotechnology, University Politehnica of Bucharest, 313 Splaiul \\ Independentei, 060042 Bucharest, Romania \\ * Correspondence: victor.guerrero@epn.edu.ec (V.H.G.); apruna@itm.upv.es (A.P.)
}

\section{check for}

updates

Citation: Asimbaya, C.; Rosas-Laverde, N.M.; Galeas, S.; Debut, A.; Guerrero, V.H.; Pruna, A. Magnetite Impregnated

Lignocellulosic Biomass for Zn(II)

Removal. Materials 2022, 15, 728.

https://doi.org/10.3390/ma15030728

Academic Editors: Piotr Piszczek,

Aleksandra Radtke and Carlos

Javier Duran-Valle

Received: 18 October 2021

Accepted: 26 November 2021

Published: 19 January 2022

Publisher's Note: MDPI stays neutral with regard to jurisdictional claims in published maps and institutional affiliations.

Copyright: (c) 2022 by the authors. Licensee MDPI, Basel, Switzerland. This article is an open access article distributed under the terms and conditions of the Creative Commons Attribution (CC BY) license (https:// creativecommons.org/licenses/by/ $4.0 /)$.

\begin{abstract}
Magnetic composites obtained by impregnation of lignocellulosic biomass with magnetite nanoparticles were used for zinc(II) removal from aqueous synthetic solutions. Laurel, canelo and eucalyptus sawdust, with a particle size between 74 and $150 \mu \mathrm{m}$ were used as support. Structural and morphological examinations of the composites confirmed the presence of magnetite nanoparticles in the lignocellulosic support. Transmission Electron Microscopy showed nanoparticles with diameters of about $20 \mathrm{~nm}$. The maximum removal efficiencies for $7 \mathrm{~g} \mathrm{~L}^{-1}$ of modified adsorbent were increased to $98.9,98.8$ and $97.6 \%$ for laurel, canelo and eucalyptus magnetic composites, respectively, in comparison to $60.9,46.0$ and $33.3 \%$, for corresponding unmodified adsorbents. Adsorption data was analyzed using pseudo-first, pseudo-second order and intra-particle diffusion kinetic models and various isotherm models. The results determined that Freundlich isotherm fits the $\mathrm{Zn}$ ions adsorption on magnetite modified adsorbents while chemisorption and boundary diffusion were dominating the process.
\end{abstract}

Keywords: aqueous synthetic solutions; magnetite nanoparticles; adsorption isotherms; diffusion kinetic models; physisorption

\section{Introduction}

The increasing industrial activity during the last decades has resulted in a worldwide concern problem: heavy metals contamination of liquid effluents. These metals have become a serious problem because their ions are not biodegradable and accumulate in animal tissues, damaging human health and water quality [1-3]. One of the most common heavy metals in industrial discharges is zinc, and the main sources of pollution are the automotive, electroplating, iron and steel industries [2,4-6].

Nowadays, several techniques are used to remove heavy metals from water, such as: sedimentation, filtration, electrocoagulation, ion exchange and reverse osmosis, however, disadvantages of these methods are low efficiency, high energy requirements, incompatibility with pollutants and toxic residues generation, that require subsequent treatments [6,7]. For these reasons, alternative treatments have been developed and optimized in the few last decades. One of the most efficient, low cost, that is widely used is adsorption [8,9].

The most common adsorbent used for heavy metal removal is activated carbon, however it is expensive. Recent studies focus on alternative materials: inexpensive, abundant in nature, with minimal processing requirement and in some cases by-products of other industries [9]. These materials include waste wood, mainly sawdust, which due to its porosity has high free surface that results in removal of heavy metals through the formation of bonds between the metal ions and the oxygen of ionizable functional groups [10]. 
Therefore, nanotechnology has allowed the development of more efficient adsorbent materials for environmental remediation. For example, iron nano-oxides (magnetite, hematite and maghemite nanoparticles) have a magnetic core that improve the adsorption process. In addition, they allow an easy recovery, handling and less contamination [11]. This, combined with the adsorptive capacity of the sawdust allows the removal of metal ions from liquid effluents to be more effective and the recovery of the residue to be easier and less expensive [12].

Numerous studies performed during the last decades have reported lignocellulosic materials impregnated with magnetic materials that have been used successfully to remove metals from contaminated water. Moafi et al. [13] used a wood sawdust/hematite $\left(\alpha-\mathrm{Fe}_{2} \mathrm{O}_{3}\right)$ nanocomposite to adsorb arsenic (III) from water with a removal capacity of $58.8 \mathrm{mg} \mathrm{g}^{-1}$. Panneerselvam et al. [5] obtained a nickel removal of $38.3 \mathrm{mg} \mathrm{g}^{-1}$ using tea residues impregnated with magnetic nanoparticles. Additionally, Gupta and Nayak [14] used orange peel residues impregnated with magnetite nanoparticles to treat cadmium-contaminated effluents and reported an adsorption capacity of $76.9 \mathrm{mg} \mathrm{g}^{-1}$.

Wood residues are widely available around the globe, are cheap and have a particularly favorable composition, structural and morphological characteristics for adsorption. For instance, Ecuador has become one of the most biodiverse countries around the world due to the variety of climates which resulted in high availability of plant species. According to National Financial Corporation [15] statistics for 2016, forest area of Ecuador was around 54,000 ha, and the annual production of wood was about 421,000 metric tons. Additionally, wood industry is well known for generating big amounts of waste, up to $70 \%$ of the wood raw materials can become chippings, sawdust or off-cuts $[16,17]$. Therefore, wood residues can be advantageously used to remove a wide variety of contaminants from aqueous solutions [18]. Although the removal of heavy metals using magnetic composite bioadsorbents has been investigated by several previous authors, the use of supporting materials derived from species such as Ecuadorian laurel (Cordia alliodora), canelo (Ocotea javitensis) and eucalyptus (Eucalyptus glodulus) has not been sufficiently analyzed. In several studies, the improvement of the adsorptive performance obtained by using particulated materials to impart magnetic properties to the adsorbents is not well defined and understood. Moreover, in some cases the study of the kinetics and equilibrium processes associated to the adsorptive removal of pollutants using this type of materials is limited to fit the experimental data obtained to a particular set of models without verifying the validity and applicability of the underlying assumptions [19]. For this reason, in this work, we studied the absorptive removal of zinc(II) ions from synthetic wastewaters by using the previously mentioned wood residues to obtain magnetic adsorbents by magnetite nanoparticles impregnation. The obtained adsorbents were characterized by using several analytical techniques and the influence of the magnetite nanoparticles on the removal performance of the composites was determined. The experimental data obtained in batch tests was fitted to a series of isotherm and kinetics models, aiming to elucidate the nature and the factors that affect the ability of the composites for capturing the metal ions in the solution.

\section{Materials and Methods}

\subsection{Materials}

Iron(III) chloride hexahydrate $\left(\mathrm{FeCl}_{3} \cdot 6 \mathrm{H}_{2} \mathrm{O}\right)$ (LOBA Chemie, Mumbai, India), iron(II) sulfate heptahydrate $\left(\mathrm{FeSO}_{4} \cdot 7 \mathrm{H}_{2} \mathrm{O}\right)$ (Panreac, Barcelona, Spain) and ammonium hydroxide solution ( $\mathrm{NH}_{4} \mathrm{OH}, 29 \%$ ) (Fisher Chemicals, New York, NY, USA). These reagents were used to obtain magnetic nanoparticles. Zinc chloride $\left(\mathrm{ZnCl}_{2}\right)$ (Merck, Kenilworth, NJ, USA) was used to prepare $\mathrm{Zn}^{2+}$ synthetic solutions for removal tests. All reagents were of analytical grade. The solutions were prepared with pure water (Type 2). Lignocellulosic residues (laurel, yellow canelo and eucalyptus wood chips) were obtained from a local sawmill in Quito, Ecuador. 


\subsection{Lignocellulosic Biomass Conditioning and Characterization}

Wood chips of laurel, canelo and eucalyptus (separately) were washed several times with water and dried at $100{ }^{\circ} \mathrm{C}$ for $12 \mathrm{~h}$, then reduced up to $0.5 \mathrm{~mm}$ with a knife-mill (Thomas Scientific, model 3379-K05, Philadelphia, PA, USA), and classified by sieving (vibratory sieve shaker, Retsch, AS 200 basic, Llanera, Spain) for $30 \mathrm{~min}$ in order to retain the fraction between 74 and $150 \mu \mathrm{m}$ to be used as support of the magnetic nanocomposites.

Chemical composition of lignocellulosic residues was determined using ASTM standards methods: D1106-96 (lignin), D1109-84 (hemicellulose), ASTM D1110-84 and D1107-96 (extractive components). Cellulose content was determined by difference. Moisture, ash and volatile matter content were measured by ASTM standards (D4442-07, D1102-84 and ASTM E872-82, respectively, ASTM International, Lima, Peru). Fixed carbon content was determined by difference. Functional groups of lignocellulosic residues were identified by Fourier Transform Infrared Spectroscopy (FTIR, Perkin Elmer, São Paulo, Brazil, Spectrum 100/Spotlight 200, range: 4000 to $500 \mathrm{~cm}^{-1}$ ). Surface morphology and particle size were determined by Scanning Electron Microscopy (SEM, Tescan, Mira 3, Quito, Ecuador) and Transmission Electron Microscopy (TEM, FEI, G2 Spirit Twin, Madrid, Spain), respectively.

\subsection{Magnetite Impregnation of Lignocellulosic Biomass and Characterization}

Magnetite nanoparticles were synthesized by controlled precipitation method. $\mathrm{FeCl}_{3} \cdot 6 \mathrm{H}_{2} \mathrm{O}$ $(6.1 \mathrm{~g})$ and $\mathrm{FeSO}_{4} \cdot 7 \mathrm{H}_{2} \mathrm{O}(4.2 \mathrm{~g})$ were added to $100 \mathrm{~mL}$ of water, heated to $35^{\circ} \mathrm{C}$ in an argon atmosphere with stirring (1250 rpm). Next, $10 \mathrm{~mL}$ of $29 \%$ ammonia solution was added and the reaction was carried out for $30 \mathrm{~min}$. Finally, the lignocellulosic residue was added to the resultant solution keeping it at $35^{\circ} \mathrm{C}$ and constant stirring for another $30 \mathrm{~min}$ (magnetite/residue ratio: 1:1). The obtained black precipitate was naturally cooled down to room temperature and thoroughly rinsed with pure water until the unreacted reagents were removed and a neutral $\mathrm{pH}$ of the solution was reached. The precipitate was magnetically separated from the solution and dried at $70^{\circ} \mathrm{C}$ for $12 \mathrm{~h}$. This procedure was performed for each type of wood.

Magnetite impregnated sorbents were characterized by X-ray Diffraction (Panalytical, Empyrean XRD with a $\mathrm{Cu} \mathrm{K} \alpha$ source, $40 \mathrm{kV}, 40 \mathrm{~mA}, 2 \theta$ range: 10 to $90^{\circ}$, Quito, Ecuador), FTIR microscopy in ATR mode (Perkin Elmer, Spectrum 100 Spectrometer with Spotlight 200 microscope, São Paulo, Brazil), SEM (Tescan, Mira 3, Quito, Ecuador) and TEM (FEI, G2 Spirit Twin, Madrid, Spain) microscopy.

\subsection{Adsorption Studies}

Batch removal tests were performed at $298 \mathrm{~K}$ in order to optimize experimental conditions. Each of the obtained nanocomposites were added to zinc chloride synthetic solutions $\left(\mathrm{ZnCl}_{2}\right)$ at constant stirring (150 rpm, orbital shaker KS 130, IKA, Staufen, Germany) and $\mathrm{pH}$ was adjusted at 6 [20], by addition of $0.1 \mathrm{M} \mathrm{NaOH}$ or $\mathrm{HCl}$ solutions. Zinc concentration after adsorption was analyzed by visible spectroscopy (HACH, DR1900, Loveland, CO, USA) as established in the APHA 3500-Zn method. All the tests were performed in duplicate [21].

The optimal contact time was determined using $50 \mathrm{mg} \mathrm{L}^{-1}$ zinc precursor solutions with adsorbent dosage of $5 \mathrm{~g} \mathrm{~L}^{-1}$. Samples were collected at 30, 45, 60, 120, 180, 240 and $300 \mathrm{~min}$ in order to determine evolution of removal process. Then, using the optimal contact time $(3 \mathrm{~h})$, the effect of adsorbent dosage on zinc removal was studied. The magnetite modified adsorbents were added to $50 \mathrm{mg} \mathrm{L}^{-1}$ zinc solutions at a dosage of 3, 5, 7 and $10 \mathrm{~g} \mathrm{~L}^{-1}$, at $\mathrm{pH}$ value of 6 . Non-modified adsorbents were employed as reference samples, in the same conditions.

Adsorption isotherms were obtained using the optimal adsorbent dosage and contact time. Zinc chloride solutions of 25, 50, 100, 150, 200 and $300 \mathrm{mg} \mathrm{L}^{-1}$ [22] were used. The experiments were carried out at $298 \mathrm{~K}$, constant stirring at $150 \mathrm{rpm}$ and $\mathrm{pH} 6$.

For the adsorption experiments, the following equation was employed to calculate the equilibrium adsorption capacity, $\mathrm{q}_{\mathrm{e}}\left(\mathrm{mg} \mathrm{g}^{-1}\right)$ of adsorbent: 


$$
\mathrm{q}_{\mathrm{e}}=\mathrm{V}\left(\mathrm{C}_{\mathrm{o}}-\mathrm{C}_{\mathrm{e}}\right) / \mathrm{m},
$$

where $\mathrm{V}(\mathrm{L})$ is the solution volume, $\mathrm{C}_{\mathrm{o}}$ and $\mathrm{C}_{\mathrm{e}}\left(\mathrm{mg} \mathrm{L}^{-1}\right)$ are the initial and equilibrium concentrations of $\mathrm{Zn}$ solutions, respectively, and $\mathrm{m}(\mathrm{g})$ is the mass of dry sorbent. The removal efficiency is calculated as a ratio between adsorbed value at time $t$ and the initial zinc concentration $\left(\mathrm{mg} \mathrm{L}^{-1}\right)$.

The Equations (2)-(4) for pseudo first-order (PFO) model (Equation (2)), pseudo secondorder (PSO) model (Equation (3)) and intra-particle diffusion model [23] (Equation (3)):

$$
\begin{gathered}
\mathrm{q}(\mathrm{t})=\mathrm{q}_{\mathrm{e}}\left(1-\mathrm{e}^{-\mathrm{k}_{1} \mathrm{t}}\right), \\
\mathrm{t} / \mathrm{q}(\mathrm{t})=1 /\left(\mathrm{k}_{2} \mathrm{q}_{\mathrm{e}}^{2}\right)+\mathrm{t} / \mathrm{q}_{\mathrm{e}} \\
\mathrm{q}(\mathrm{t})=\mathrm{k}_{\mathrm{p}} \mathrm{t}^{0.5}+\mathrm{C}
\end{gathered}
$$

were used to analyze the kinetic data, where $\mathrm{q}(\mathrm{t})\left(\mathrm{mg} \mathrm{g}^{-1}\right)$ is the amount of $\mathrm{Zn}$ adsorbed on the sorbent at any time $\mathrm{t}(\mathrm{h}), \mathrm{k}_{1}\left(\mathrm{~min}^{-1}\right), \mathrm{k}_{2}\left(\mathrm{~g}(\mathrm{mg} \mathrm{min})^{-1}\right)$ and $\mathrm{k}_{\mathrm{p}}\left(\mathrm{g} \mathrm{mg}^{-1} \mathrm{~min}^{-0.5}\right)$ are the PFO, PSO and intraparticle diffusion kinetic model constants, respectively.

The adsorption isotherm data was fitted with Langmuir, Freundlich and Temkin models in their linearized forms as described by Equations (5)-(7) and the non-linear forms as given in Equations (8)-(10) [24], by using Origin 8.5 software (OriginLab Corp., Northampton, MA, USA):

$$
\begin{gathered}
\frac{\mathrm{C}_{\mathrm{e}}}{\mathrm{q}_{\mathrm{e}}}=\frac{1}{\left(\mathrm{q}_{\mathrm{m}} \times \mathrm{K}_{\mathrm{L}}\right)}+\frac{1}{\mathrm{q}_{\mathrm{m}}} \mathrm{C}_{\mathrm{e}} \\
\log \mathrm{q}_{\mathrm{e}}=\frac{1}{\mathrm{n}} \log \mathrm{C}_{\mathrm{e}}+\log \mathrm{K}_{\mathrm{F}} \\
\mathrm{q}_{\mathrm{e}}=\mathrm{B} \ln \mathrm{K}_{\mathrm{T}}+\mathrm{B} \ln \mathrm{C}_{\mathrm{e}} \\
\mathrm{q}_{\mathrm{e}}=\frac{\mathrm{C}_{\mathrm{e}} \mathrm{q}_{\mathrm{m}} \mathrm{K}_{\mathrm{L}}}{1+\mathrm{K}_{\mathrm{L}} \mathrm{C}_{\mathrm{e}}} \\
\mathrm{q}_{\mathrm{e}}=\mathrm{K}_{\mathrm{F}} \mathrm{C}_{\mathrm{e}}{ }^{1 / \mathrm{n}} \\
\mathrm{q}_{\mathrm{e}}=\mathrm{q}_{\mathrm{m}} \ln \left(\mathrm{K}_{\mathrm{T}} \mathrm{C}_{\mathrm{e}}\right)
\end{gathered}
$$

where $\mathrm{q}_{\mathrm{e}}$ is the amount of solute adsorbed at equilibrium per adsorbent unit weight $\left(\mathrm{mg} \cdot \mathrm{g}^{-1}\right), \mathrm{C}_{\mathrm{e}}$ represents the concentration of solute at equilibrium $\left(\mathrm{mg} \cdot \mathrm{L}^{-1}\right)$, $\mathrm{qm}_{\mathrm{m}}$ represents the maximum adsorption capacity $\left(\mathrm{mg} \mathrm{g}^{-1}\right), \mathrm{K}_{\mathrm{L}}$ is the Langmuir isotherm constant $\left(\mathrm{L} \mathrm{mg}^{-1}\right), \mathrm{K}_{\mathrm{F}}$ is the Freundlich isotherm constant $\left(\mathrm{L} \mathrm{g}^{-1}\right), \mathrm{n}$ is the coefficient of the Freundlich equation related to heterogeneity (measure of adsorption linearity), $\mathrm{B}$ is related to sorption heat and $\mathrm{K}_{\mathrm{T}}\left(\mathrm{L} \mathrm{mg}^{-1}\right)$ is Temkin isotherm equilibrium binding constant. The sum of squares error (SSE) is employed to estimate the goodness of non-linear fit. The best model is characterized by the smallest SSE value.

The Dubinin-Radushkevich isotherm model was also evaluated by using the Equation (11):

$$
\ln \mathrm{q}_{\mathrm{e}}=\ln \mathrm{q}_{\mathrm{m}}-\beta \varepsilon^{2},
$$

where

$$
\varepsilon=\mathrm{RT} \ln \left(1+1 / \mathrm{C}_{\mathrm{e}}\right),
$$

where $\mathrm{q}_{\mathrm{m}}\left(\mathrm{mg} \mathrm{Zn} \mathrm{g}{ }^{-1}\right)$ is the maximum adsorption capacity, $\beta\left(\mathrm{mol}^{2} \mathrm{~kJ}^{-2}\right)$ is a coefficient related to the mean sorption energy, $\varepsilon$ is the Polanyi potential, $\mathrm{R}\left(\mathrm{J} \mathrm{mol}^{-1} \mathrm{~K}^{-1}\right)$ is the gas constant and $\mathrm{T}(\mathrm{K})$ is the absolute temperature. The sorption energy $\mathrm{E}\left(\mathrm{kJ} \mathrm{mol}^{-1}\right)$ is given by:

$$
\mathrm{E}=1 / \sqrt{-2 \beta}
$$

The fittings of the experimental data collected to three different kinetics models aimed to study the adsorption rate and the rate-controlling step during the removal of the heavy metal ions. The first two models considered, PFO and PSO, are reaction kinetics models that are usually adequate for cases in which there is a high and low concentration of the pollutant in the solution, respectively. In the PSO model, chemisorption is supposed to be 
the rate-controlling step in the process. In the third model considered, the rate-controlling step is the intraparticle diffusion of the pollutant into the pores of the adsorbent. This model is usually adequate for porous adsorbents $[25,26]$.

\section{Results}

\subsection{Adsorbents Characterization}

\subsubsection{Chemical Composition of Lignocellulosic Biomass}

In wood, the major component is cellulose and lignin [19]. Studies performed during the last decades $[19,20]$, showed that lignin plays a significant role in the removal of heavy metals due to the presence of phenolic groups. However, this is not the predominant factor, since there are other components such as hemicellulose that have ionizable carboxylic groups in their composition that contribute to the adsorption of metal ions. As shown in Table 1, the values in this study, vary between 63 and $74 \%$ for cellulose, while lignin content varied from 18 to $32 \%$.

Table 1. Chemical composition and proximate analysis of the lignocellulosic biomass.

\begin{tabular}{ccccc}
\hline & Component & Laurel & Canelo & Eucalyptus \\
\hline \multirow{5}{*}{ Chemical composition } & Cellulose [wt \%] & 50.20 & 53.49 & 58.44 \\
& Lignin [wt \%] & 31.84 & 28.28 & 18.28 \\
& Hemicellulose [wt \%] & 12.76 & 12.45 & 16.01 \\
& Extractives [wt \%] & 5.20 & 5.78 & 7.27 \\
\hline \multirow{5}{*}{ Proximate analysis } & Volatile matter [wt \%] & 70.94 & 78.70 & 81.52 \\
& Fixed carbon [wt \%] & 17.99 & 12.93 & 12.54 \\
& Ash content [wt \%] & 1.38 & 0.16 & 0.25 \\
& Moisture [wt \%] & 9.69 & 8.21 & 5.69 \\
\hline
\end{tabular}

\subsubsection{Infrared Spectroscopy}

Figure 1 shows FTIR spectra of the lignocellulosic residues and the magnetic composites. The laurel, canelo and eucalyptus residues showed similar spectra to literature [27] with bands located at 3332,3341 and $3322 \mathrm{~cm}^{-1}$, respectively, which correspond to O-H bond stretches of phenol and alcohol groups. The bands at 2895, 2895 and $2903 \mathrm{~cm}^{-1}$ attributed to the $\mathrm{C}-\mathrm{H}$ bonds stretches of the aliphatic chains, while 1733,1734 and $1736 \mathrm{~cm}^{-1}$ bands correspond to $\mathrm{C}=\mathrm{O}$ groups [28]. Characteristic bands of lignin for laurel, canelo and eucalyptus were seen at 1502, 1505 and $1502 \mathrm{~cm}^{-1}$, respectively, which correspond to the benzene ring vibration. Bands at 1733, 1734 and $1736 \mathrm{~cm}^{-1}$ are attributed to the carbonyl group vibration of cellulose and hemicellulose. Bands between 1154 and $1024 \mathrm{~cm}^{-1}$ represent the vibrational stretching of the $\mathrm{C}-\mathrm{OH}$ groups. Although very weak, the bands at 577,591 and $571 \mathrm{~cm}^{-1}$, respectively in the magnetic composites of laurel, canelo and eucalyptus could be attributed to the $\mathrm{Fe}-\mathrm{O}$ bond in magnetite $[5,12]$. Such weak bands could be attributed to the region of the sample studied in ATR mode. Nevertheless, their presence could be also retrieved by a slight shift in the biomass bands upon modification. Moreover, as the microscopy and diffraction measurements further show, the presence of magnetite is confirmed.

\subsubsection{Scanning and Transmission Electron Microscopy}

Figure 2 shows SEM images of lignocellulosic residues and composite materials. Non-homogeneous surfaces with smooth sections are seen in the lignocellulosic residues. Magnetic composites show rough surfaces due to the presence of magnetite nanoparticles deposited on the lignocellulosic residue surfaces. Agglomerates of different size are formed due to the magnetic properties of the nanoparticles and the high surface area [29]. TEM images of magnetite particles (a) and magnetic composite of laurel (b) are shown in Figure 3. These pictures reveal nanoscaled quasi-spherical particles with particle diameter of $20 \mathrm{~nm}$, approximately. In previous studies $[6,30,31]$, for similar synthesis methods of magnetite nanoparticles, particles with size between 10 and $50 \mathrm{~nm}$ and a similar geometry to this 
study were obtained [32]. Furthermore, according to Shahid and Choi, the dissolutionrecrystallization, occurring during coprecipitation process is responsible for the spherical shape of the magnetite nanoparticles [32]. An aggregation phenomenon is evident in the magnetite nanoparticles, which could be attributed to the small size and their magnetic properties. This phenomenon seems to be reduced in the composites as the particles are distributed on the lignocellulosic matrix surface.

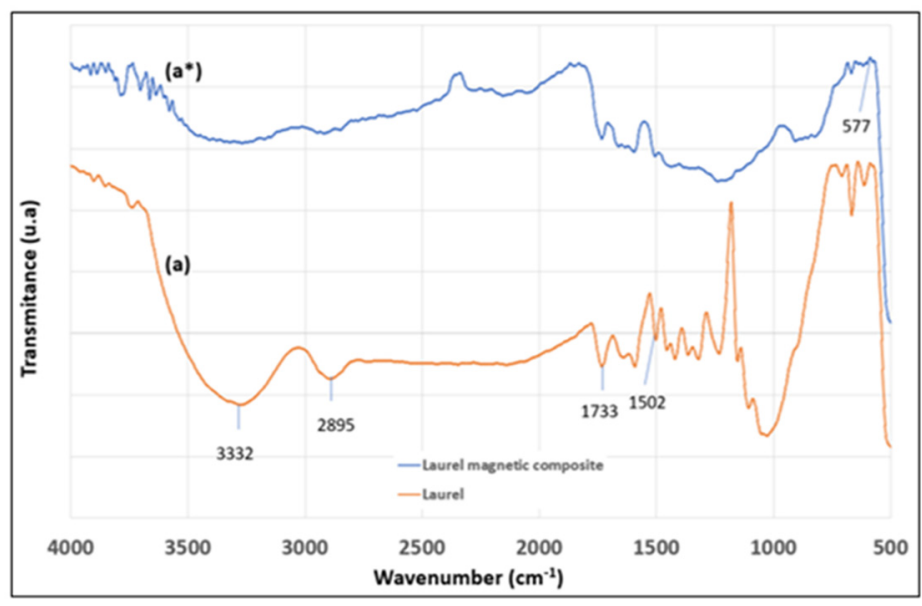

(a)

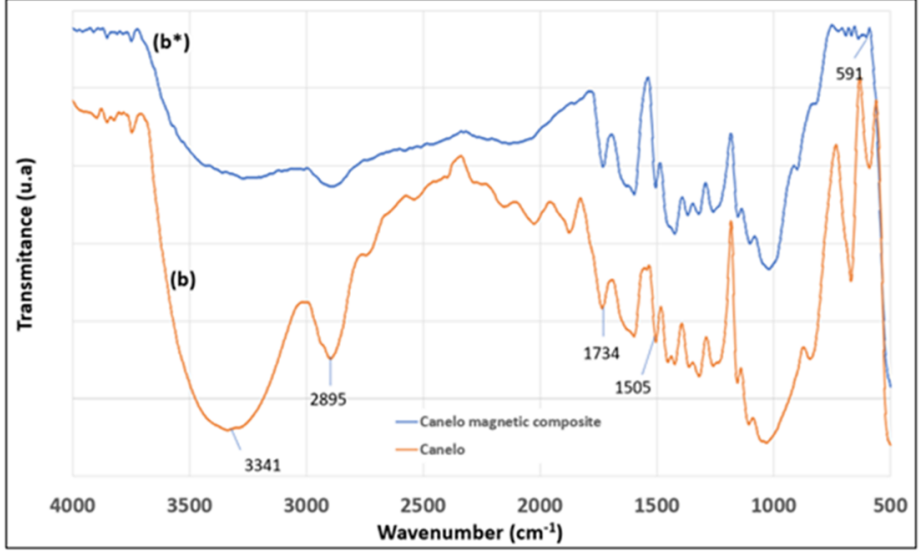

(b)

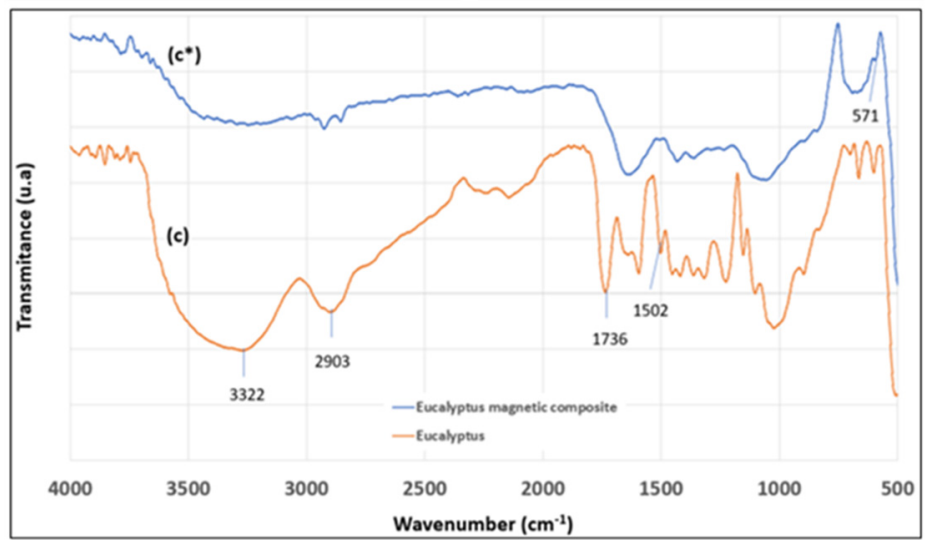

(c)

Figure 1. FTIR spectra of lignocellulosic biomass before $(\mathrm{x})$ and after impregnation with magnetite $\left(x^{*}\right)$ : (a) (a* vs. a) laurel, (b) (b* vs. b) canelo and (c) ( $c^{*}$ vs. c) eucalyptus. 

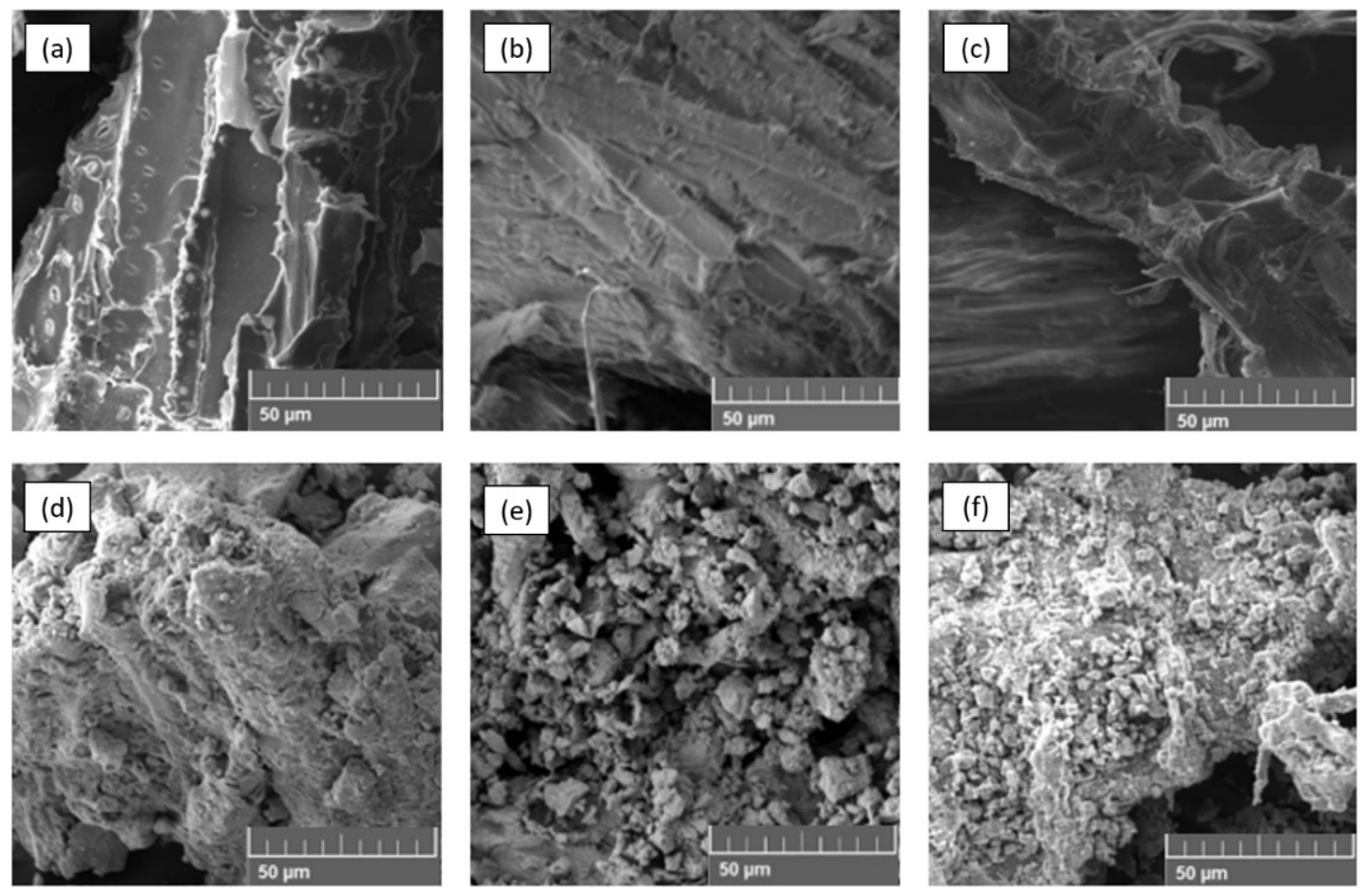

Figure 2. SEM image of non-impregnated lignocellulosic biomass from: (a) eucalyptus, (b) canelo and (c) laurel, and their magnetite impregnated counterparts: (d-f).
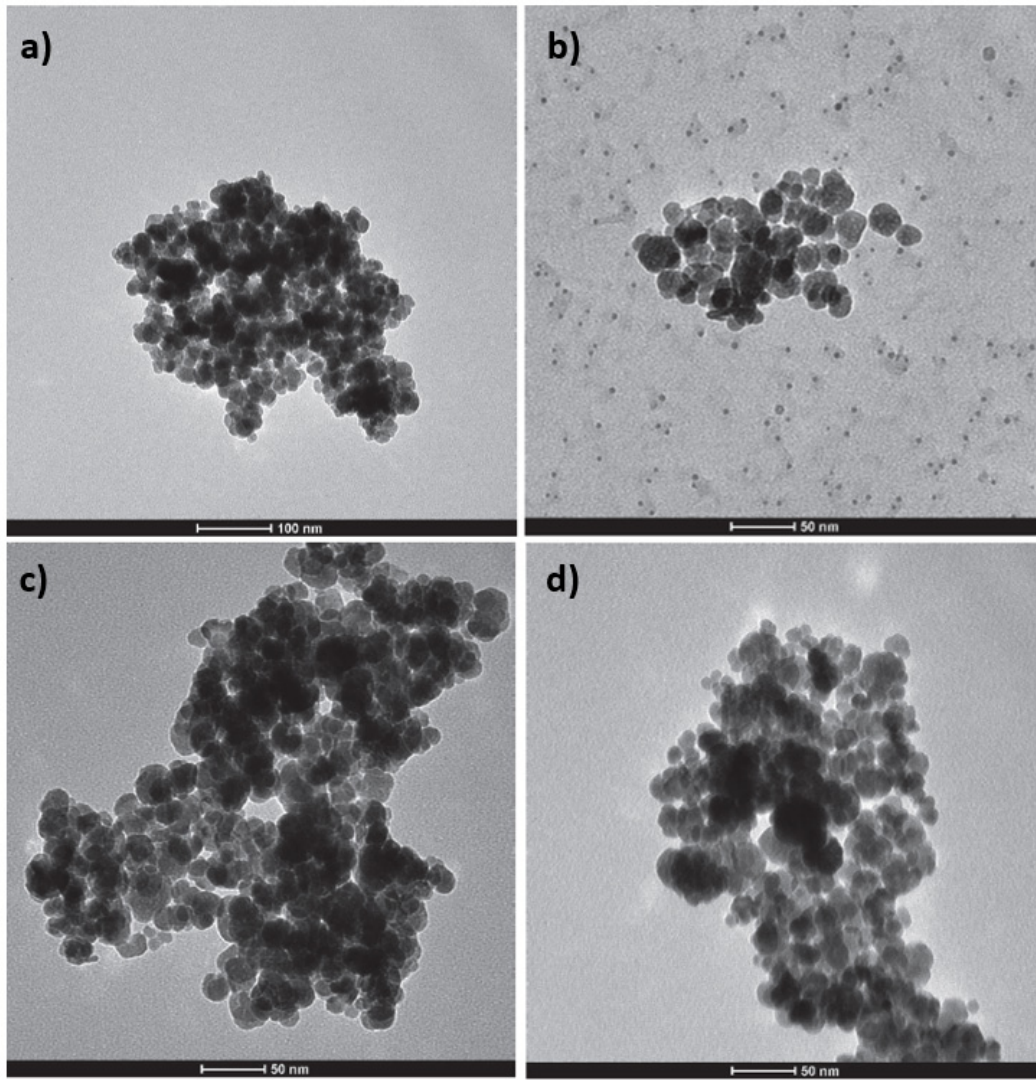

Figure 3. TEM images of the magnetite nanoparticles (a) and magnetite modified sorbent: canelo (b), eucalyptus (c) and laurel (d). 


\subsubsection{X-ray Diffraction}

Figure 4 shows the $\mathrm{X}$-ray diffraction patterns of magnetite and magnetic composites. Peaks at $30.0^{\circ}, 35.5^{\circ}, 43.0^{\circ}, 53.5^{\circ}, 57.0^{\circ}$ and $62.5^{\circ}$ corresponding to indices (220), (311), (400), (422), (511) and (440), were observed. These peaks correspond to a cubic spinel structure of magnetite [29]. Based on these results, the presence of magnetite in the composite material can be verified. The same behavior was observed for canelo and eucalyptus magnetic composites. According to the Scherrer equation mentioned elsewhere [33], the crystallite size calculated for magnetite nanoparticles, and magnetite modified laurel, canelo and eucalyptus composites were $10 \mathrm{~nm}, 15.3 \mathrm{~nm}, 19.5 \mathrm{~nm}$ and $13.5 \mathrm{~nm}$, respectively. These results are comparable to the sizes observed with TEM and reported scale values [32].

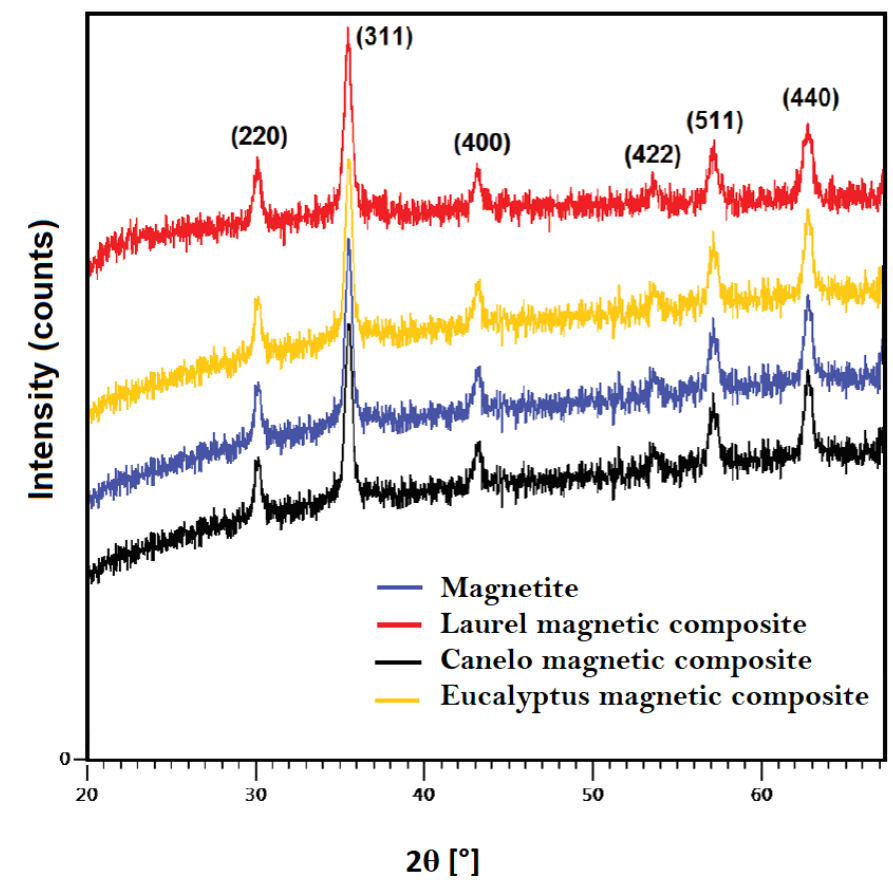

Figure 4. X-ray diffraction pattern of magnetite nanoparticles and magnetic composites.

\subsection{Adsorption Studies}

\subsubsection{Optimal Time and Adsorbent Dosage}

The effect of contact time on adsorption of zinc was studied. As shown in Figure 5, the three magnetic composites have the same behavior. The adsorption rate was fast for the first minutes, after 60 min this rate decreases significantly. According to Zhang et al. [34], during the first few minutes, the adsorbent has many free active sites, and as the adsorption process progresses they are occupied by zinc ions. Furthermore, they generate repulsive forces towards the ions still present in the treated solution, which makes it difficult to occupy all the active sites on the adsorbent surface.

It was observed that after $60 \mathrm{~min}$ the $\mathrm{Zn}$ (II) removal exceeds $95 \%$ for the three composite materials and the equilibrium was achieved after $180 \mathrm{~min}$. This time was considered as the optimal time for the next tests.

Figure 6 shows the effect of adsorbent dosage on zinc removal from synthetic solutions. It is observed for the three lignocellulosic residues (left) that the dosage has a direct influence in the adsorption efficiency. Laurel sawdust showed the maximum removal percentage $(60.9 \%)$ of the three residues, which could be attributed to the lignin content of the lignocellulosic residue. For the magnetic composites (right), it is observed a maximum removal of $98.9,98.8$ and $97.6 \%$ for laurel, canelo and eucalyptus magnetic composites, respectively, when using $7 \mathrm{~g} \mathrm{~L}^{-1}$ of adsorbent. By using higher dosages of adsorbent $\left(10 \mathrm{~g} \mathrm{~L}^{-1}\right)$, the removal percentage does not increase which is attributed to a higher dispute 
over available active sites. Thus, the number of agglomerates increases, which causes the diffusion path to be longer and the adsorption process gets hindered [13].

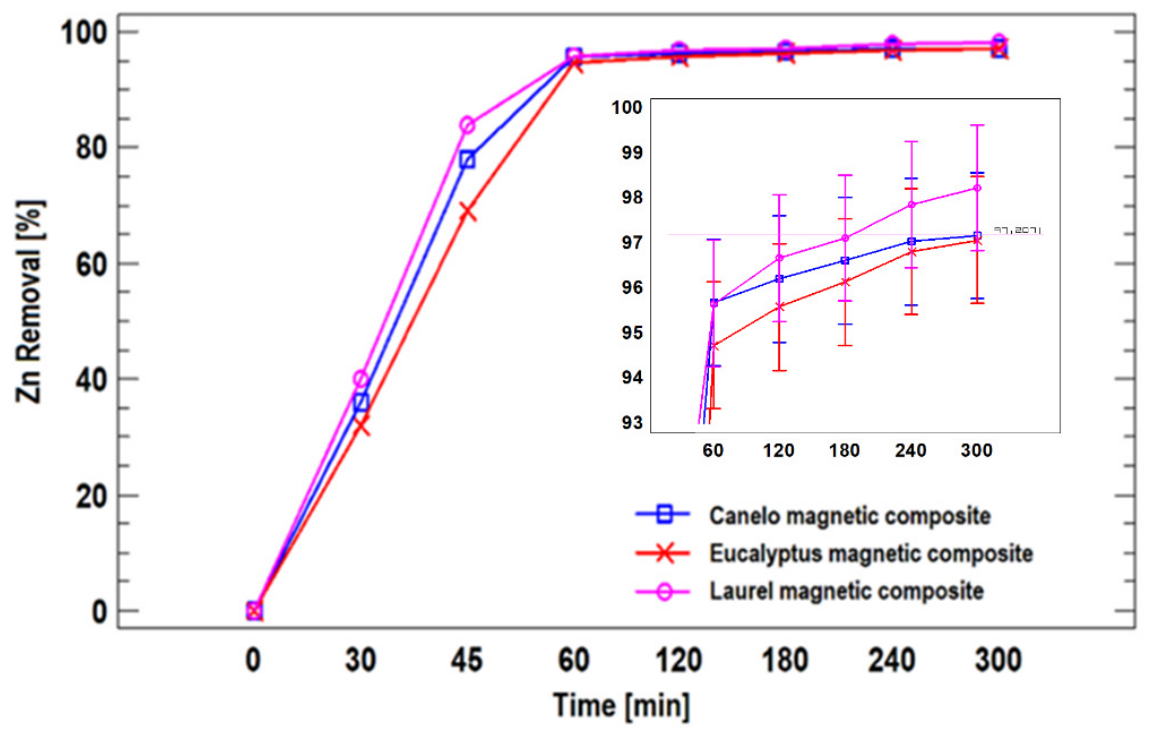

Figure 5. Contact time effect on zinc removal using magnetic composites.

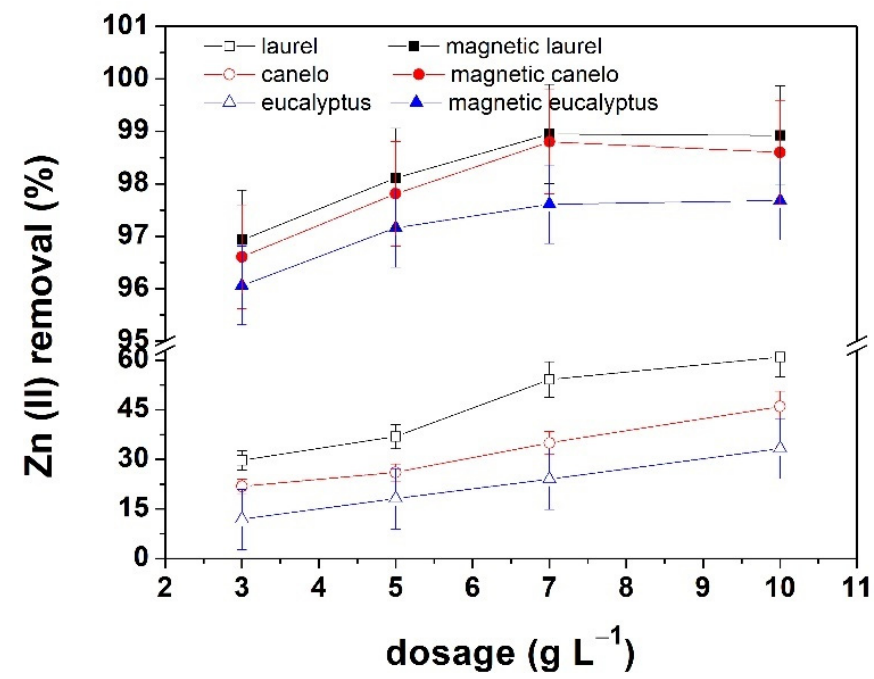

Figure 6. Effect of adsorbent dosage on zinc removal using lignocellulosic biomass before and after magnetite impregnation.

When comparing the results obtained in the zinc removal, it is observed that the addition of magnetite nanoparticles to lignocellulosic residues improve notably the removal percentage. For laurel, the zinc removal increases from 60.9 to $98.9 \%$. This behavior occurs due to the presence of nanoparticles, which considerably increases the surface area. Furthermore, the $\mathrm{Fe}$ and $\mathrm{O}$ atoms of the nanoparticles adsorb $\mathrm{OH}^{-}$radicals from the solution, causing their surface to become rich in $\mathrm{OH}^{-}$groups. This increases the interactions between these groups and the metal ions in the solution, which makes the removal process more efficient [31].

\subsubsection{Adsorption Kinetics}

As shown in Figure 7a-c, the $\mathrm{Zn}$ adsorption rates on the magnetite modified canelo, laurel and eucalyptus waste-based adsorbents increased rapidly in the initial stage and then gradually decreased reaching an equilibrium state. This behavior could be explained by the existence of numerous accessible active sites on the adsorbent surface and thus, when they 
get occupied, the adsorption rate decreases. The kinetics of the removal of $\mathrm{Zn}(\mathrm{II})$ ions using magnetite modified adsorbents was fitted by both pseudo-first order model (PFO) and pseudo-second order model (PSO) and the corresponding plots are given in Figure 7a-c. As it is clearly observed, the fitted values of $q$ were closer to the experimental ones for PSO kinetic model for magnetite modified laurel and canelo adsorbents, which is indicative of the suitability of PSO model for the adsorption kinetics of $\mathrm{Zn}$ on the obtained bio-sorbents.
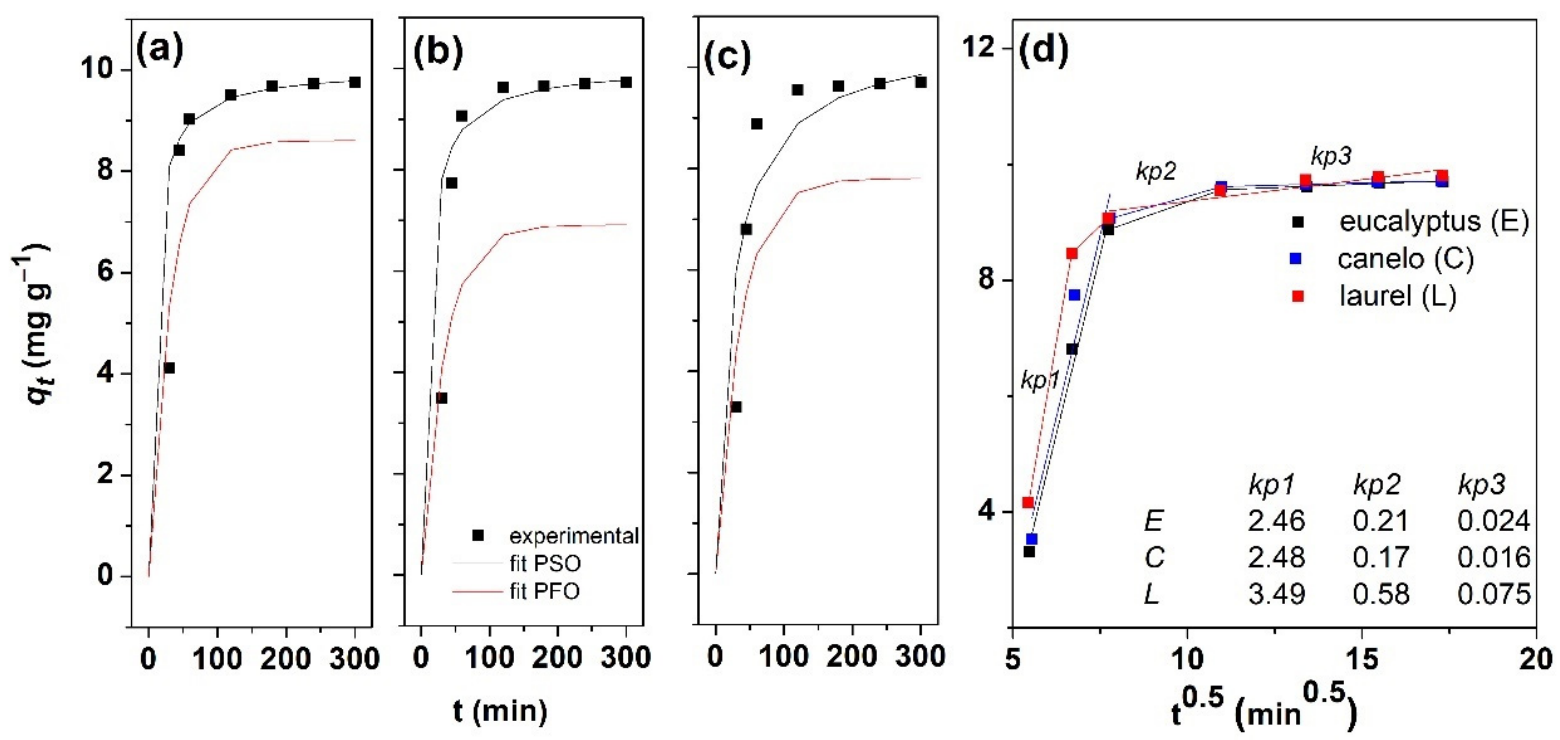

Figure 7. Adsorption kinetics of $\mathrm{Zn}$ on magnetite modified lignocellulosic waste-based adsorbents: laurel (a), canelo (b) and eucalyptus (c). Weber-Morris plot for intraparticle diffusion kinetics of $\mathrm{Zn}$ adsorption on magnetite eucalyptus modified adsorbent (d).

The parameters corresponding to the fitting of kinetic models are further given in the Table 2. The correlation coefficient, $\mathrm{R}^{2}$, obtained from the linear regression analysis was used to analyze the linear forms for PFO and PSO models. Thus, the higher values of $R^{2}$ for PSO with respect to the PFO ones (above 0.963), confirm a better fit of the adsorption process by PSO model, independently of the employed adsorbent. This indicates that Zn adsorption process on each magnetic adsorbent could be controlled by chemisorption [35,36], which is also supported by the results of the adsorbent characterization (presence of active sites/functional groups). The fitted adsorption capacities are similar for the modified adsorbents, reaching a value of about $10 \mathrm{mg} \mathrm{g}^{-1}$. On the other hand, the parameter $h$ increases from eucalyptus to canelo and laurel magnetite-modified adsorbents, indicating the initial adsorption has the highest rate for laurel-based adsorbent. Such results could be attributed to the biomass structure and functional groups [37]. The adsorption rate constants obtained from the plots were decreasing from $0.0141,0.0116$ and $0.0041 \mathrm{~g} \mathrm{mg}^{-1} \mathrm{~min}^{-1}$ for laurel, canelo and eucalyptus, respectively.

Table 2. Kinetics parameters for $\mathrm{Zn}(\mathrm{II})$ ions removal using the magnetite impregnated adsorbents.

\begin{tabular}{cccccccc}
\hline \multirow{2}{*}{ Lignocellulosic Biomass } & \multicolumn{3}{c}{ Pseudo First-Order } & \multicolumn{3}{c}{ Pseudo Second-Order } \\
\cline { 2 - 8 } & $\mathbf{q}_{\mathbf{e}}\left[\frac{\mathbf{m g} \mathbf{~ Z n}}{\mathbf{g}}\right]$ & $\mathbf{k}_{1}\left[\mathbf{m i n}^{-1}\right]$ & $\mathbf{R}^{\mathbf{2}}$ & $\mathbf{q}_{\mathbf{e}}\left[\frac{\mathbf{m g} \mathbf{~ Z n}}{\mathbf{g}}\right]$ & $\mathbf{k}_{2}\left[\frac{\mathbf{g}}{\mathbf{m g ~ Z n} \times \mathbf{m i n}}\right]$ & $\mathbf{h}\left[\frac{\mathbf{m g} \mathbf{~ Z n}}{\mathbf{g} \times \mathbf{m i n}}\right]$ & $\mathbf{R}^{\mathbf{2}}$ \\
\hline Laurel & 8.602 & 0.0323 & 0.873 & 10.013 & 0.0141 & 1.412 & 0.998 \\
Canelo & 6.913 & 0.0296 & 0.946 & 10.052 & 0.0116 & 1.171 & 0.999 \\
Eucalyptus & 7.81 & 0.0275 & 0.947 & 10.613 & 0.0041 & 0.456 & 0.963 \\
\hline
\end{tabular}

Despite the good fit of PSO for laurel and canelo based sorbents, the low $\mathrm{R}^{2}$ values obtained for eucalyptus sorbent for both PFO and PSO models suggest that a different model could fit the adsorption behavior of the obtained materials, as the sorbent supports have similar characteristics. Thus, intraparticle diffusion model as proposed by Weber 
and Morris was employed. This model assumes that the rate is not limited by mass transfer from the bulk solution to the external surface of adsorbent as the solution is stirred during the sorption period [38]. Thus, the corresponding plot would be linear [39]. Figure $7 \mathrm{~d}$ shows multi-linear plots for all sorbents, where the first step is attributed to fast (instantaneous) adsorption of Zn on the sorbent surface, the second step is characterized by a slower sorption due to diffusion of $\mathrm{Zn}$ ions into the inner adsorption sites of the adsorbent material, that would be the rate-limiting stage and a third step which corresponds to the equilibrium when the sorbent gets saturated with the ions. This behavior is similar to that of other adsorbents in literature $[40,41]$. As it can be observed in Figure 7c (kp, $\mathrm{mg} \mathrm{g}^{-1} \min ^{-0.5}$ ), the intra-particle diffusion rate constant for the first step is the highest for laurel and followed by canelo and eucalyptus with similar values, that is initial adsorption process is faster on laurel-based sorbent. The second and third steps are characterized by similar trend of the constants. Since the constant value was markedly higher for the first step than the other two, the boundary diffusion is indicated as dominating the process followed by the intra-particle diffusion.

\subsubsection{Adsorption Isotherms}

In order to better understand the adsorption of $\mathrm{Zn}$ ions on the obtained magnetite modified adsorbents, linearized forms of Langmuir, Freundlich and Temkin models were used for fitting. The corresponding plots are showed in Figure 8, respectively. Langmuir model is employed for homogeneous adsorption which assumes monolayer adsorption in the absence of interaction or steric hindrance between adsorbed molecules. The D-R model considers on the other hand a porous structure of adsorbent with heterogeneous surface. The Freundlich model is suitable for the adsorption on heterogeneous surfaces. The Temkin model assumes uniform binding energies and that the sorption heat decreases linearly as the sorbent surface gets covered with the ions.
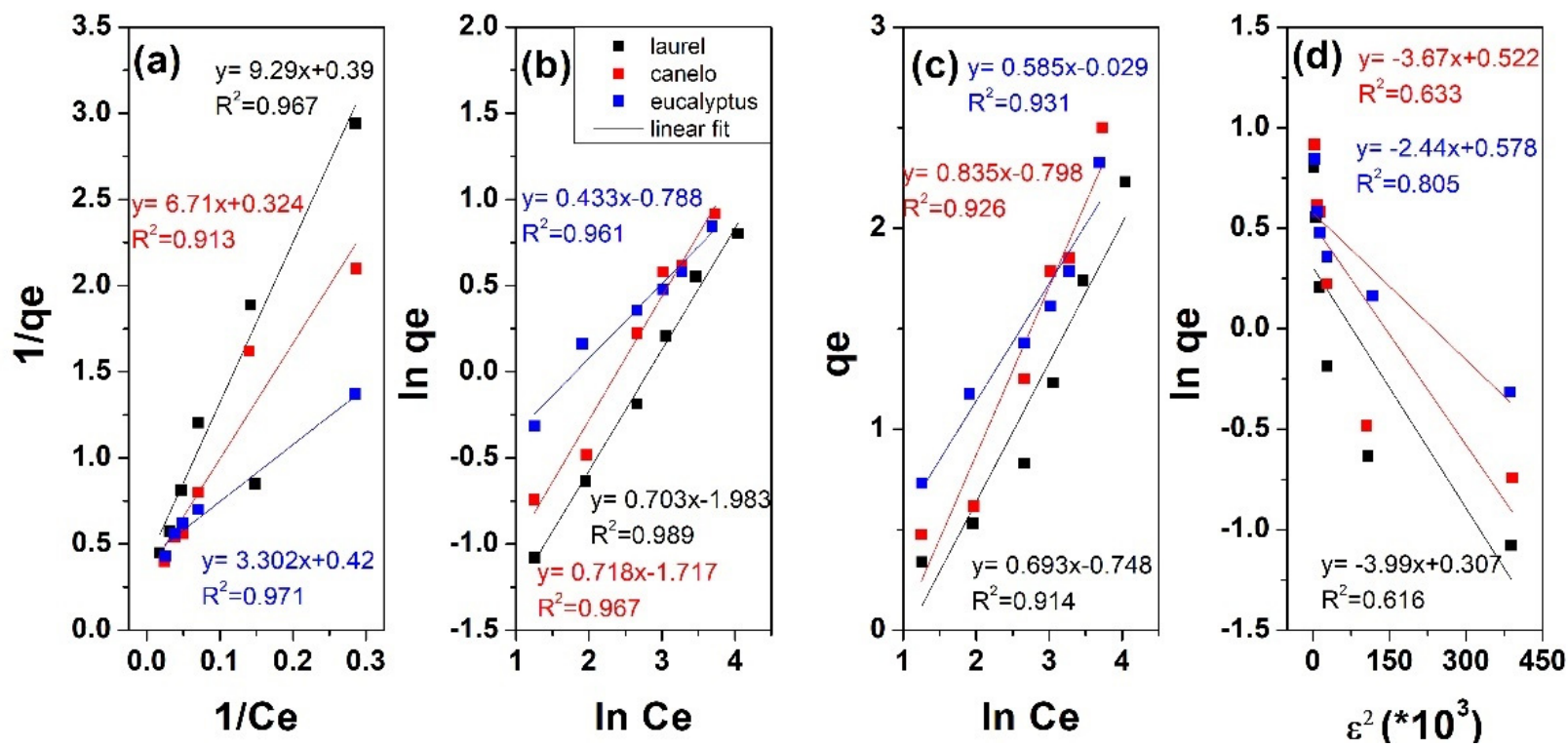

Figure 8. Linear regression analysis of $\mathrm{Zn}$ ions adsorption of magnetite modified adsorbents by Langmuir (a); Freundlich (b); Temkin (c) and Dubinin-Radushkevich (d), $\left(\varepsilon^{2}\right.$ value multiplied with $\left.10^{3}\right)$ models.

As it can be observed from Figure 8, the Langmuir, Freundlich and Temkin fittings resulted in correlation coefficient $\mathrm{R}^{2}$ above 0.9 . The adsorption parameters from the linear fitting are further presented in Table 3. 
Table 3. Linear adsorption isotherm fitting parameters on magnetic adsorbents.

\begin{tabular}{ccccc}
\hline $\begin{array}{c}\text { Isotherm } \\
\text { Model/Adsorbent }\end{array}$ & Parameter & Laurel & Canelo & Eucalyptus \\
\hline \multirow{2}{*}{ Langmuir } & $\mathrm{q}_{\mathrm{m}} \mathrm{mg} \mathrm{g}^{-1}$ & 0.11 & 0.15 & 0.31 \\
& $\mathrm{~K}_{\mathrm{L}}\left(\mathrm{L} \mathrm{mg}^{-1}\right)$ & 23.8 & 20.7 & 7.9 \\
& $\mathrm{R}^{2}$ & 0.967 & 0.913 & 0.971 \\
\hline \multirow{2}{*}{ Freundlich } & $\mathrm{q}_{\mathrm{m}} \mathrm{mg} \mathrm{g}^{-1}$ & 2.31 & 2.61 & 2.18 \\
& $\mathrm{~K}_{\mathrm{F}}\left(\mathrm{L} \mathrm{g}^{-1}\right)$ & 0.12 & 0.18 & 0.5 \\
& $\mathrm{n}$ & 1.25 & 1.39 & 2.31 \\
& $\mathrm{R}^{2}$ & 0.989 & 0.967 & 0.961 \\
\hline \multirow{2}{*}{ Temkin } & $\mathrm{K}_{\mathrm{T}}\left(\mathrm{L} \mathrm{mg}^{-1}\right)$ & 0.89 & 0.38 & 0.95 \\
& $\mathrm{~B}$ & 0.69 & 0.84 & 0.58 \\
& $\mathrm{R}^{2}$ & 0.914 & 0.926 & 0.931 \\
\hline \multirow{2}{*}{$\mathrm{D}-\mathrm{R}$} & $\mathrm{Xm},\left(\mathrm{mg} \mathrm{g}^{-1}\right)$ & 1.36 & 1.68 & 1.78 \\
& $\mathrm{E},\left(\mathrm{kJ} \mathrm{mol}^{-1}\right)$ & 0.353 & 0.37 & 0.452 \\
& $\mathrm{R}^{2}$ & 0.616 & 0.633 & 0.805 \\
\hline
\end{tabular}

By comparing the correlation coefficient values, one can observe larger values above 0.96 for Freundlich model which indicates better fitting with this model, independently of adsorbent. This suggests the $\mathrm{Zn}$ adsorption on the magnetite modified laurel, canelo and eucalyptus adsorbents takes place via multilayer adsorption on heterogeneous surfaces where active sites have different adsorption capacity. The fitting parameters show Freundlich constant (adsorption intensity) decreasing in the order eucalyptus $>$ canelo $>$ laurel for the magnetite modified adsorbents along with increasing $n$ value, and thus indicating the $\mathrm{Zn}$ adsorption is more favorable on eucalyptus modified adsorbent.

From Langmuir fitting, it can be seen that $\mathrm{q}_{\mathrm{m}}$ slightly decreased from eucalyptus to laurel along with an increase in $\mathrm{K}_{\mathrm{L}}$ value. Temkin model can be employed in order to explain the interactions between $\mathrm{Zn}$ ions and the sorbent in regard to the heat of adsorption indicated by the $\mathrm{B}$ parameter. It was observed that $\mathrm{K}_{\mathrm{T}}$ was the highest for eucalyptus and laurel, while B decreased in the order eucalyptus, canelo, laurel magnetite-modified adsorbents, indicating physical adsorption process.

The order of the isotherm best fits in this work is Freundlich $>$ Langmuir $>$ Temkin. Although such isotherms are widely employed, they do not give information in regards to the mechanism of sorption. For this purpose, the Dubinin-Radushkevich (D-R) isotherm model employed for adsorption process taking place on both homogeneous and heterogeneous surfaces was further applied for modelling the adsorption process (see Table 3 for fitting parameters). The correlation fitting $\mathrm{R}^{2}$ value is below 0.8 , indicating poor fitting with this model. The maximum adsorbed amount decreased from eucalyptus to laurel sorbent while and the sorption energy decreased in the same order and indicated a physical nature of the adsorption process [42]. The $X_{m}$ value is slightly smaller than $\mathrm{q}_{\mathrm{m}}$ which could be attributed to the different definition of $\mathrm{q}_{\mathrm{m}}$ in the models.

On the other hand, given the errors introduced by the linearized forms of the isotherm models, non-linear regression is preferable and more relevant to estimate the isotherm model parameters. The plots are represented in Figure 9 showing the fitting curves for each model with respect to the experimental data. The fitting parameters are depicted in Table 4. It can be observed that the non-linear regression resulted in $\mathrm{R}^{2}$ values similar to those from linear regression. The SSE values decreased in the order Temkin $<$ Langmuir $<$ Freundlich for all sorbents. As the best fit is indicated by lower SSE values, it can be concluded that Freundlich non-linear model best fits the adsorption on the obtained materials. 

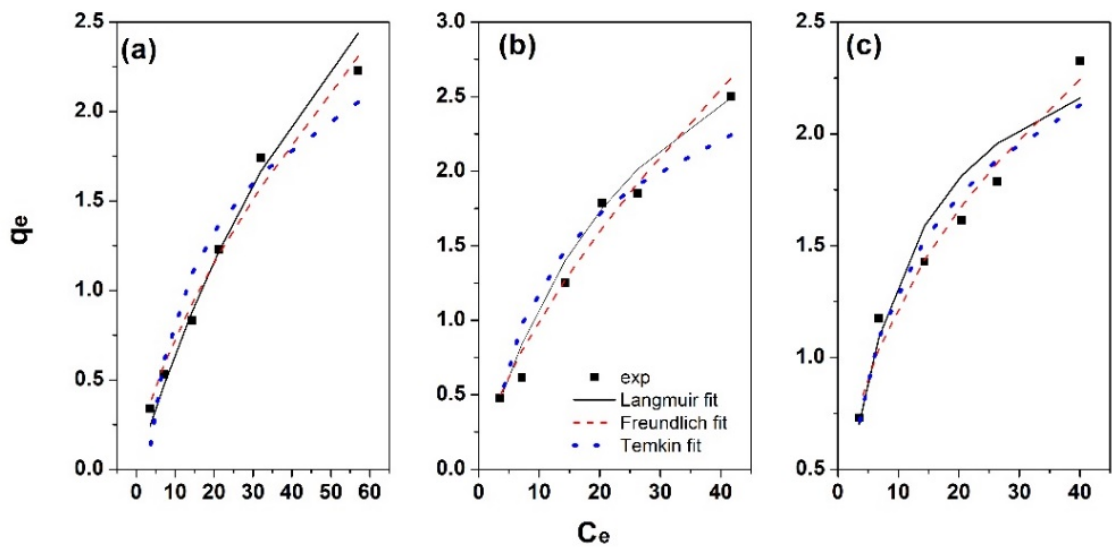

Figure 9. Non-linear regression models of $\mathrm{Zn}$ ions adsorption on magnetite modified adsorbents: laurel (a), canelo (b) and eucalyptus (c).

Table 4. Non-linear adsorption isotherm fitting parameters on magnetic adsorbents.

\begin{tabular}{ccccc}
\hline $\begin{array}{c}\text { Isotherm } \\
\text { Model/Adsorbent }\end{array}$ & Parameter & Laurel & Canelo & Eucalyptus \\
\hline \multirow{4}{*}{ Langmuir } & $\mathrm{q}_{\mathrm{m}} \mathrm{mg} \mathrm{g}^{-1}$ & 6 & 4.2 & 2.7 \\
& $\mathrm{~K}_{\mathrm{L}}\left(\mathrm{L} \mathrm{mg}^{-1}\right)$ & 0.012 & 0.035 & 0.1 \\
& $\mathrm{R}^{2}$ & 0.971 & 0.956 & 0.978 \\
& $\mathrm{SSE}$ & 0.065 & 0.1 & 0.078 \\
\hline \multirow{5}{*}{ Freundlich } & $\mathrm{q}_{\mathrm{m}} \mathrm{mg} \mathrm{g}^{-1}$ & 2.31 & 2.62 & 2.24 \\
& $\mathrm{~K}_{\mathrm{F}}\left(\mathrm{L} \mathrm{g}^{-1}\right)$ & 0.16 & 0.21 & 0.454 \\
& $\mathrm{n}$ & 1.52 & 1.48 & 2.31 \\
& $\mathrm{R}^{2}$ & 0.989 & 0.972 & 0.966 \\
Temkin & $\mathrm{SSE}$ & 0.046 & 0.08 & 0.039 \\
\hline & $\mathrm{K}_{\mathrm{T}}\left(\mathrm{L} \mathrm{mg}^{-1}\right)$ & 0.34 & 0.54 & 0.951 \\
& $\mathrm{~B}$ & 0.693 & 0.72 & 0.585 \\
& $\mathrm{R}^{2}$ & 0.914 & 0.921 & 0.931 \\
& $\mathrm{SSE}$ & 0.182 & 0.248 & 0.081 \\
\hline
\end{tabular}

To verify the suitability of the magnetite modified composite as adsorbents, a comparison with reports on other similar adsorbents in the literature was performed. Although direct comparison of the maximum adsorption capacity $\mathrm{q}_{\mathrm{m}}$ of studied lignocellulosic biomass-based adsorbents with literature is difficult, owing to the different experimental conditions, the maximum adsorption capacity obtained is in line with other reports on either same biomass sorbents (different analyte) [43] or adsorbents for Zn(II) obtained from various biomass such as Lagenaria vulgaris shell [44], modified orange peel [45] or [46] or magnetic water hyacinth [47]. Considering these findings and the cost-effective source of the obtained adsorbents, the laurel, canelo and eucalyptus biomass is considered a promising alternative to obtain highly effective adsorbents for water treatment.

\section{Conclusions}

Laurel, canelo and eucalyptus residues were used as support of magnetic composites to be used as adsorbents in zinc removal from synthetic solutions. XRD, FTIR, SEM and TEM analysis showed that magnetite nanoparticles with diameters of approximately $20 \mathrm{~nm}$ were obtained and that were effectively impregnated in lignocellulosic matrices. Impregnation of magnetite in the lignocellulosic matrices of laurel, canelo and eucalyptus increased the zinc removal in 79.7, 172.3 and $282.2 \%$, respectively, in comparison to the lignocellulosic residues alone. The optimal contact time was $3 \mathrm{~h}$ and an adsorbent dosage of $7 \mathrm{~g} / \mathrm{L}$ allowed the maximum removal of zinc, which was about $98.9,98.8$ and $97.6 \%$ for laurel, canelo and eucalyptus magnetic composites, respectively. The adsorption of zinc on 
magnetite modified adsorbents is best fit by the isotherm models: Freundlich $>$ Langmuir $>$ Temkin $>$ Dubinin-Radushkevich, indicating multilayer adsorption on heterogeneous surfaces while kinetics models shown the adsorption process is dominated by both the chemisorption and diffusion.

Author Contributions: Conceptualization, N.M.R.-L. and C.A.; formal analysis, C.A. and S.G.; investigation, characterization A.D., C.A., N.M.R.-L., S.G. and V.H.G.; writing-original draft preparation, C.A. and S.G.; writing-review and editing N.M.R.-L., S.G., V.H.G. and A.P. All authors have read and agreed to the published version of the manuscript.

Funding: This research was funded by Escuela Politécnica Nacional, project grants PIMI-14-18 and PIGR-19-05.

Institutional Review Board Statement: Not applicable.

Informed Consent Statement: Not applicable.

Data Availability Statement: The data presented in this study are available on request from the corresponding author.

Acknowledgments: The authors thank David Castro for useful discussion on adsorption analysis.

Conflicts of Interest: The authors declare no conflict of interest. The funders had no role in the design of the study; in the collection, analyses, or interpretation of data; in the writing of the manuscript, or in the decision to publish the results.

\section{References}

1. Singh, J.; Kalamdhad, A.S. Effects of Heavy Metals on Soil, Plants, Human Health and Aquatic Life Making bricks using variety of solid waste View project Anaerobic digestion View project. Int. J. Res. Chem. Environ. 2011, 1, 15-21.

2. Ali, A.; Saeed, K.; Mabood, F. Removal of chromium (VI) from aqueous medium using chemically modified banana peels as efficient low-cost adsorbent. Alexandria Eng. J. 2016, 55, 2933-2942. [CrossRef]

3. Setyono, D.; Valiyaveettil, S. Chemically modified sawdust as renewable adsorbent for arsenic removal from water. ACS Sustain. Chem. Eng. 2014, 2, 2722-2729. [CrossRef]

4. Miretzky, P.; Cirelli, A.F. Cr(VI) and Cr(III) removal from aqueous solution by raw and modified lignocellulosic materials: A review. J. Hazard. Mater. 2010, 180, 1-19. [CrossRef]

5. Panneerselvam, P.; Morad, N.; Tan, K.A. Magnetic nanoparticle $\left(\mathrm{Fe}_{3} \mathrm{O}_{4}\right)$ impregnated onto tea waste for the removal of nickel(II) from aqueous solution. J. Hazard. Mater. 2011, 186, 160-168. [CrossRef] [PubMed]

6. Sureshkumar, V.; Kiruba Daniel, S.C.G.; Ruckmani, K.; Sivakumar, M. Fabrication of chitosan-magnetite nanocomposite strip for chromium removal. Appl. Nanosci. 2016, 6, 277-285. [CrossRef]

7. Abdolali, A.; Guo, W.S.; Ngo, H.H.; Chen, S.S.; Nguyen, N.C.; Tung, K.L. Typical lignocellulosic wastes and by-products for biosorption process in water and wastewater treatment: A critical review. Bioresour. Technol. 2014, 160, 57-66. [CrossRef] [PubMed]

8. Owalude, S.O.; Tella, A.C. Removal of hexavalent chromium from aqueous solutions by adsorption on modified groundnut hull. Beni-Suef Univ. J. Basic Appl. Sci. 2016, 5, 377-388. [CrossRef]

9. Gakwisiri, C.; Raut, N.; Al-Saadi, A.; Al-Aisri, S.; Al-Ajmi, A. A critical review of removal of zinc from wastewater. Lect. Notes Eng. Comput. Sci. 2012, 2197, 627-630.

10. Hegazi, H.A. Removal of heavy metals from wastewater using agricultural and industrial wastes as adsorbents. HBRC J. 2013, 9 , 276-282. [CrossRef]

11. Hua, M.; Zhang, S.; Pan, B.; Zhang, W.; Lv, L.; Zhang, Q. Heavy metal removal from water/wastewater by nanosized metal oxides: A review. J. Hazard. Mater. 2012, 211-212, 317-331. [CrossRef]

12. Cheng, Z.; Gao, Z.; Ma, W.; Sun, Q.; Wang, B.; Wang, X. Preparation of magnetic $\mathrm{Fe}_{3} \mathrm{O}_{4}$ particles modified sawdust as the adsorbent to remove strontium ions. Chem. Eng. J. 2012, 209, 451-457. [CrossRef]

13. Moafi, H.F.; Ansari, R.; Sadeghnia, S. Preparation of wood sawdust $/ \mathrm{Fe}_{2} \mathrm{O}_{3}$ nanocomposite and its application for arsenic (III) ion removal from aqueous solutions. Cellul. Chem. Technol. 2018, 52, 271-282.

14. Gupta, V.K.; Nayak, A. Cadmium removal and recovery from aqueous solutions by novel adsorbents prepared from orange peel and $\mathrm{Fe}_{2} \mathrm{O}_{3}$ nanoparticles. Chem. Eng. J. 2012, 180, 81-90. [CrossRef]

15. CFN. Ficha Sectorial: Explotación De Viveros Forestales y Madera En Pie; CFN: Quito, Ecuador, 2017.

16. Daian, G.; Ozarska, B. Wood waste management practices and strategies to increase sustainability standards in the Australian wooden furniture manufacturing sector. J. Clean. Prod. 2009, 17, 1594-1602. [CrossRef] 
17. Chompu-Inwai, R.; Jaimjit, B.; Premsuriyanunt, P. A combination of Material Flow Cost Accounting and design of experiments techniques in an SME: The case of a wood products manufacturing company in northern Thailand. J. Clean. Prod. 2015, 108, 1352-1364. [CrossRef]

18. Zamora-Ledezma, C.; Negrete-Bolagay, D.; Figueroa, F.; Zamora-Ledezma, E.; Ni, M.; Alexis, F.; Guerrero, V.H. Heavy metal water pollution: A fresh look about hazards, novel and conventional remediation methods. Press 2021, 22, 101504. [CrossRef]

19. Hubbe, M.A.; Azizian, S.; Douven, S. Implications of Apparent Pseudo-Second-Order Adsorption Kinetics onto Cellulosic Materials: A Review. BioResources 2019, 14, 7582-7626. [CrossRef]

20. Sciban, M.; Klasnja, M.; Skrbic, B. Modified hardwood sawdust as adsorbent of heavy metal ions from water. Wood Sci. Technol. 2006, 40, 217-227. [CrossRef]

21. Šćiban, M.; Radetić, B.; Kevrešan, Ž.; Klašnja, M. Adsorption of heavy metals from electroplating wastewater by wood sawdust. Bioresour. Technol. 2007, 98, 402-409. [CrossRef]

22. Bulut, Y.; Tez, Z. Removal of heavy metals from aqueous solution by sawdust adsorption. J. Environ. Sci. 2007, 19, 160-166. [CrossRef]

23. Weber, W.J., Jr.; Morris, J.C. Kinetics of Adsorption on Carbon from Solution. J. Sanit. Eng. Div. 1963, 89, 31-59. [CrossRef]

24. Okumu, F. A Novel Polyaniline Titanium Oxide Sawdust Composite Adsorbent for Polychlorinated Biphenyls. Sci. J. Chem. 2013, 1, 29. [CrossRef]

25. McCoy, M.A.; Liapis, A.I. Evaluation of kinetic models for biospecific adsorption and its implications for finite bath and column performance. J. Chromatogr. A 1991, 548, 25-60. [CrossRef]

26. Almeida-naranjo, C.E.; Belén, M.; Cabrera, G.; Guerrero, V.H. Caffeine removal from synthetic wastewater using magnetic fruit peel composites: Material characterization, isotherm and kinetic studies. Environ. Challenges 2021, 5, 100343. [CrossRef]

27. Azzaz, A.A.; Jellali, S.; Assadi, A.A.; Bousselmi, L. Chemical treatment of orange tree sawdust for a cationic dye enhancement removal from aqueous solutions: Kinetic, equilibrium and thermodynamic studies. Desalin. Water Treat. 2016, 57, 22107-22119. [CrossRef]

28. Md Salim, R.; Asik, J.; Sarjadi, M.S. Chemical functional groups of extractives, cellulose and lignin extracted from native Leucaena leucocephala bark. Wood Sci. Technol. 2021, 55, 295-313. [CrossRef]

29. Petcharoen, K.; Sirivat, A. Synthesis and characterization of magnetite nanoparticles via the chemical co-precipitation method. Mater. Sci. Eng. B Solid-State Mater. Adv. Technol. 2012, 177, 421-427. [CrossRef]

30. Tajabadi, M.; Khosroshahi, M.E. Effect of Alkaline Media Concentration and Modification of Temperature on Magnetite Synthesis Method Using $\mathrm{FeSO}_{4} / \mathrm{NH}_{4} \mathrm{OH}$. Int. J. Chem. Eng. Appl. 2012, 3, 206-210. [CrossRef]

31. Nethaji, S.; Sivasamy, A.; Mandal, A.B. Preparation and characterization of corn cob activated carbon coated with nano-sized magnetite particles for the removal of Cr(VI). Bioresour. Technol. 2013, 134, 94-100. [CrossRef]

32. Shahid, M.K.; Choi, Y. Characterization and application of magnetite Particles, synthesized by reverse coprecipitation method in open air from mill scale. J. Magn. Magn. Mater. 2020, 495, 165823. [CrossRef]

33. Fujimoto, K.; Oku, T.; Akiyama, T. Fabrication and Characterization of $\mathrm{ZnO} / \mathrm{Cu}_{2} \mathrm{O}$ Solar Cells Prepared by Electrodeposition. Appl. Phys. Express 2013, 6, 086503. [CrossRef]

34. Zhang, Y.; Zheng, R.; Zhao, J.; Zhang, Y.; Wong, P.K.; Ma, F. Biosorption of zinc from aqueous solution using chemically treated rice husk. Biomed Res. Int. 2013, 2013, 365163. [CrossRef] [PubMed]

35. Feng, N.C.; Guo, X.Y.; Liang, S. Kinetic and thermodynamic studies on biosorption of Cu(II) by chemically modified orange peel. Trans. Nonferrous Met. Soc. China Engl. Ed. 2009, 19, 1365-1370. [CrossRef]

36. Zhao, H.; Liu, X.; Cao, Z.; Zhan, Y.; Shi, X.; Yang, Y.; Zhou, J.; Xu, J. Adsorption behavior and mechanism of chloramphenicols, sulfonamides, and non-antibiotic pharmaceuticals on multi-walled carbon nanotubes. J. Hazard. Mater. 2016, 310, 235-245. [CrossRef]

37. Ertugay, N.; Bayhan, Y.K. The removal of copper (II) ion by using mushroom biomass (Agaricus bisporus) and kinetic modelling. Desalination 2010, 255, 137-142. [CrossRef]

38. Zhu, S.; Hou, H.; Xue, Y. RETRACTED: Kinetic and isothermal studies of lead ion adsorption onto bentonite. Appl. Clay Sci. 2008, 40, 171-178. [CrossRef]

39. Nandi, B.K.; Goswami, A.; Purkait, M.K. Adsorption characteristics of brilliant green dye on kaolin. J. Hazard. Mater. 2009, 161, 387-395. [CrossRef]

40. Behnamfard, A.; Salarirad, M.M. Equilibrium and kinetic studies on free cyanide adsorption from aqueous solution by activated carbon. J. Hazard. Mater. 2009, 170, 127-133. [CrossRef] [PubMed]

41. Tan, I.A.W.; Ahmad, A.L.; Hameed, B.H. Adsorption of basic dye on high-surface-area activated carbon prepared from coconut husk: Equilibrium, kinetic and thermodynamic studies. J. Hazard. Mater. 2008, 154, 337-346. [CrossRef]

42. Wang, C.C.; Juang, L.C.; Hsu, T.C.; Lee, C.K.; Lee, J.F.; Huang, F.C. Adsorption of basic dyes onto montmorillonite. J. Colloid Interface Sci. 2004, 273, 80-86. [CrossRef]

43. León, G.; Aldás, M.; Guerrero, V.; Landázuri, A.; Almeida-Naranjo, C. Caffeine and irgasan removal from water using bamboo, laurel and moringa residues impregnated with commercial $\mathrm{TiO}_{2}$ nanoparticles. MRS Adv. 2019, 4, 3553-3567. [CrossRef]

44. Mitic-Stojanovic, D.-L.; Bojic, D.; Mitrovic, J.; Andjelkovic, T.; Radovic, M.; Bojic, A. Equilibrium and kinetic studies of Pb(II), $\mathrm{Cd}(\mathrm{II})$ and $\mathrm{Zn}(\mathrm{II})$ sorption by Lagenaria vulgaris shell. Chem. Ind. Chem. Eng. Q. 2012, 18, 563-576. [CrossRef] 
45. Feng, N.C.; Guo, X.Y. Characterization of adsorptive capacity and mechanisms on adsorption of copper, lead and zinc by modified orange peel. Trans. Nonferrous Met. Soc. China Engl. Ed. 2012, 22, 1224-1231. [CrossRef]

46. Castro, D.; Rosas-Laverde, N.M.; Aldás, M.B.; Almeida-naranjo, C.; Guerrero, V.H.; Pruna, A.I. Chemical modification of agro-industrial waste-based bioad- sorbents for enhanced removal of $\mathrm{Zn}$ (II) ions from aqueous solutions. Materials 2021, 14, 2134. [CrossRef]

47. Nyamunda, B.C.; Chivhanga, T.; Guyo, U.; Chigondo, F. Removal of Zn (II) and Cu (II) ions from industrial wastewaters using magnetic biochar derived from water hyacinth. J. Eng. 2019, 2019, 5656983. [CrossRef] 